\title{
Assessment of the potential mobility of copper in contaminated soil samples by column leaching test
}

\author{
Belabbes Kandsi a, Karim Benhabib b, Goussem Mimanne a, \\ Mebarka Djellouli a,*, Safia Taleb a
}

${ }^{a}$ Laboratory of Materials and Catalysis, Department of Chemistry, Faculty of Exact Sciences, Djillali Liabès University, Algeria bEco-Process, Optimization and Decision Support (EPROAD, EA 4669), Jules Verne University of Picardie, France

\section{Article Info}

Received : 02.06.2018

Accepted : 13.11 .2018

\begin{abstract}
Column leaching tests become methodology important for assessing the risk of release of pollutants from soil into groundwater. In this present study column leaching test were applied on soil samples taken directly in the vicinity of Kenadsa coking plant (Algeria) in order to evaluate the mobility of copper and their potential environmental risks. These samples have been lixiviated in laboratory column in water-saturated condition at room temperature. All leachates have been collected by fraction and analyzed from copper and dissolved organic carbon. The percentages leached in column with water are very low (< $1 \%$ ). The concentrations of copper in the resulting leachates do not present a toxicological hazard. The effect of dissolved organic carbon on copper leaching was also investigated in this study; the results of column leaching showed that the mobility of copper in these contaminated soil samples is associated with the mobility of dissolved organic carbon.
\end{abstract}

Keywords: Contaminated soil, copper, column experiment, dissolved organic carbon.

(c) 2019 Federation of Eurasian Soil Science Societies. All rights reserved

\section{Introduction}

Mining and associated activities have a negative impact on the environment both during the mining operations and for years after mine closure. The soils in the vicinity of this mining may contain high levels of organic pollutants particularly polycyclic aromatic hydrocarbons (PAHs) and heavy metals. It is essential to predict their mobility and fate and to evaluate the risk of transfer to sensitive targets, such as water resources, ecosystems and human health.

In the commune of Kenadsa (south-west of Algeria), since 1962, the date of the stop of the exploitation of coals in the Kenadsa mine, the problem of the environment is still talked about, where hills of waste pollute this site. A study conducted by Kadari et al. (2015) put the action on the pollution of the soil samples collected on this site by the polycyclic aromatic hydrocarbons (PAHs). In addition, the preliminary analysis of soil samples taken in the vicinity of this aged coking plant showed that such soil samples were polluted by heavy metals and especially by copper.

The behavior of Copper in the soil depends on many factors: the pH of the soil, its redox potential, its capacity of cationic exchange, the type and the distribution of organic matter, the presence of oxides, the speed of decomposition of the organic matter, the proportions of clays, silts and sands, the climate and the type of vegetation present (Adriano, 1986; Dameron and Howe, 1998; Picard et al., 2005).

The best-known method for studying the transport and mobility of Heavy metals in polluted soils is the leaching test, which extracts the elements of interest in order to quantify the potential risk of their mobility.

\footnotetext{
${ }^{*}$ Corresponding author.

Laboratory of Materials and Catalysis, Department of Chemistry, Faculty of Exact Sciences, Djillali Liabès University, BP 89,22000 Sidi Bel Abbès, Algeria

Tel.: +213556386840

E-mail address: mebarkad@yahoo.fr

e-ISSN: 2147-4249 DOI: 10.18393/ejss.485939
} 
Column leaching test are widely used to predict the mobility of heavy metals (Temminghoff et al., 1997; Voegelin et al. 2003; Xu et al.2005; Kalbe et al., 2008; Cappuyns and Swennen, 2008; Mouni et al., 2016). The principle of the experiments in column consists in placing a quantity of soil in a column and subjecting it to a leaching solution by ascending/descending percolation, then the measurement of the quantity of the pollutants in the leachates thus obtained. Column tests give a better simulation of field conditions than batch tests (e.g. more realistic L/S ratio, laminar instead of turbulent flow) (Cappuyns and Swennen, 2008). In addition; the percolation of water through materials in column tests is so far to the closest simulation to natural conditions in comparison with any other leaching tests and at the same time provides the most reliable results (Kalbe et al., 2008).

The aim of this study is to evaluate the contamination of soil samples taken directly in the vicinity of Kenadsa coking plant and the potential release as well as the mobility of copper. The potential release and mobility of copper was estimated by column leaching tests. Moreover, copper is famous for its affinity with the organic matter of the soil, therefore it is interesting at the time of studying the risk to be able to determine a correlation between the mobility of copper and dissolved organic carbon (DOC) in kenadsa soil samples.

\section{Material and Methods}

\section{Origin and preparation of studied soils}

Kenadsa soil samples been collected in the vicinity of abandoned coking plant, located in the commune of Kenadsa (South-west of Algeria), with geographic location, Latitude N 31 $33^{\circ} 32^{\prime \prime}$ and Longitude W $2^{\circ} 25^{\prime}$ 24". A study conducted by Kadari et al (2015) shown that the soil samples collected on this site were contaminated by polycyclic aromatic hydrocarbons $\left(\mathrm{PAH}_{\mathrm{S}}\right)$. For our study, Approximately $15 \mathrm{~kg}$ of a soil samples were prepared by collecting 1-2 kg of soil samples with a small stainless at depth of $0-20 \mathrm{~cm}$ at 11 points. This quantity was homogenized by quartering, screened at $4 \mathrm{~cm}$ and air dried at $20^{\circ} \mathrm{C}$. A 5 -kg subsample was taken and sieved at $2 \mathrm{~mm}$; the fraction $(<2 \mathrm{~mm})$ was used in this work, prior to laboratory analysis and column leaching testes. The sample thus prepared was stored in plastic bags and kept refrigerator at $+4^{\circ} \mathrm{C}$ until use.

Since, there is no information available on the local background values for Algerian soils in this area of study. Control soil obtained about 4 kilometers southern from the studied area, which assumed to have background concentration of analyzed elements. The procedure of sampling and preparing the soil control were the same of sampling and preparing of kenadsa soil samples.

\section{Characterization physicochemical of studied soils}

The solutions used were prepared with demineralized water. All the reagents used were of trace pure grade (Merck, Sigma-Aldritch). All the equipment (glassware, polyethylene bottles, etc.) were systematically decontaminated using $\mathrm{HNO}_{3}(10 \%$, v/v).In addition, reagent blanks were analyzed to verify the absence of contamination and precision of the analysis. For each test, three tests were carried out, but only the mean of the results obtained is presented.

Percentages of sand $(2-0.05 \mathrm{~mm})$, silt $(0.05-0.002 \mathrm{~mm})$, and clay $(<0.002 \mathrm{~mm})$ were determined by wet sieving method and the hydrometer method. The moisture content was determined by measuring the mass loss of the soil following its drying at $105^{\circ} \mathrm{C}$ for $24 \mathrm{~h}$. Soil $\mathrm{pH}$ in water was determined with a pH meter using $5: 1$ (v/ v) water/soil suspensions. The total organic carbon was determined according to the Anne modified method (Mathieu and Pieltain, 2003). Cation exchange capacity (CEC) was determined by the $0.05 \mathrm{~N}$ cobalthexamine method according to the standard (ISO 23470).

The Chemical compositions in major elements ( $\mathrm{Fe}, \mathrm{Al}, \mathrm{Mg}, \mathrm{Ca}, \mathrm{Si}, \mathrm{S}, \mathrm{K}, \mathrm{P}$, and $\mathrm{Na}$ ) were determined by $\mathrm{X}$-ray Fluorescence Spectrometer (PW 2400 -Philips -in Alicante University - Spain). Pseudo total concentration of Heavy metals $(\mathrm{Cu}, \mathrm{Ni}, \mathrm{Cr}, \mathrm{Zn})$ were measured using flame atomic absorption spectrometry (FAAS, Thermofisher model 651074), after Wet digstion by aqua regia (proportion in volume of $2 / 3$ of $\mathrm{HCl}$ at $37 \%$ and a $1 / 3$ of $\mathrm{HNO}_{3}$ at $65 \%$ ) according to the standard (ISO 11466). The calibration was performed using standard SCP Science.

\section{Column experiments}

Column leaching tests were carried to simulate the release of pollutants following rainwater infiltration. The principal of Column leaching tests was inspired in the work of Benhabib (Benhabib et al., 2017). The experimental set-up was composed of a borosilicate glass column (XK 26/20) from (GE Healthcare, Sweden) with an inner diameter of $2.6 \mathrm{~cm}$. This column was powered by a peristaltic pump (Heidolph model 5206, 
Germany) capable of ensuring a constant flow rate of 2 to $3900 \mathrm{ml} / \mathrm{min}$. All these elements (column, pump, tanks) are connected by Teflon capillary tubes with an inner diameter of $0.8 \mathrm{~mm}$. Column was filled with about $83 \mathrm{gr}$ (dry mass) of Kenadsa soil $(<2 \mathrm{~mm})$ for a $12.5 \mathrm{~cm}$ height, The bulk density was approximately $1.25\left(\mathrm{gr} \mathrm{cm}^{-1}\right)$. Leaching experiments and tracing were carried out successively without replacing the soil sample at room temperature $\left(20 \pm 2{ }^{\circ} \mathrm{C}\right)$. The column filled with soil was previously saturated from bottom to top with demineralized water at a flow rate of $2 \mathrm{~mL} \mathrm{~min}^{-1}$. The experiment started at the end of the column saturation at a constant flow rate of $2 \mathrm{~mL} \mathrm{~min}^{-1}$. It consists in continuously sweeping the column with demineralized water to reach a liquid-to-solid ratio $\left(\mathrm{L} / \mathrm{S}=10 \mathrm{~mL} \mathrm{gr}^{-1}\right)$ of dry soil corresponding to 830 $\mathrm{mL}$ leached (This report is used to compare our results with other standardized batch or column tests). During the leaching, $50 \mathrm{~mL}$ fractions were continuously collected. The $\mathrm{pH}$, conductivity of the leachates was measured. Then, the leachates were then filtered at $0.45 \mu \mathrm{m}$ and the concentrations of copper and DOC was measured in the filtrates. Concentrations of copper were measured using graphite furnace atomic absorption spectroscopy (GF-AAS, THERMOFISHER model 651074), the limit of Detection for copper was $0.06 \mu \mathrm{g} \mathrm{L}^{-1}$. The DOC was measured by a TOC meter (SieversInnov0x; Version 3.01).

A tracing experiment was run on column at the end of the leaching experiment, non-reactive tracer (sodium nitrate) tests were conducted to characterize the hydrodynamic properties of soil column and verify reproducibility of experiments. The column was fed by a $2 \times 10^{-3} \mathrm{~mol} \mathrm{~L}^{-1} \mathrm{NaNO}_{3}$ solution until conductivity at the outlet reached conductivity of the feed solution. A step-wise injection of a $10^{-2} \mathrm{~mol} \mathrm{~L}^{-1} \mathrm{NaNO}_{3}$ solution was then done until conductivity stabilization, followed by a step-wise injection of the $2 \times 10^{-3} \mathrm{~mol} \mathrm{~L}^{-1} \mathrm{NaNO}_{3}$ solution.

\section{Results and Discussion}

\section{Physicochemical properties of studied soils}

The main physico-chemical properties of studied soils are presented in Table 1. By deferring the percentages of sand, silt and clay in the texture triangle proposed by the United States Department of Agriculture (USDA), the Kenadsa soil has a sandy texture; Its $\mathrm{pH}$ is slightly alkaline, the $\mathrm{pH}$ of this soil is in a range indicating a priori a propensity of this soil to fix the heavy metals (generally between 6.5 and 8.5 ). The organic carbon content is high (12.6\%) as well as organic matter (MO) (21.8\%); this is due to the presence of a large amount of aromatic hydrocarbon in this coking plant soil (Kadari et al., 2015). The CEC of kenadsa soil is low; characteristic of a sandy soil poor in the limestone, despite the presence of a large amount of organic matter. Concentrations of major elements (mean of three replicates) in Kenadsa soil samples (\% in mass) determined by X-ray spectrofluorometer were: $\mathrm{SiO}_{2}: 54.12, \mathrm{Fe}_{2} \mathrm{O}_{3}: 4.81 ; \mathrm{Na}_{2} \mathrm{O}: 0.45 ; \mathrm{MgO}: 1.51 ; \mathrm{Al}_{2} \mathrm{O}_{3}: 10.52$; $\mathrm{CaO}: 8.78, \mathrm{~K}_{2} \mathrm{O}: 1.90 ; \mathrm{SO}_{3}: 11.97 ; \mathrm{P}_{2} \mathrm{O}_{5}$ : 0.48; others: 0.83 .

Table 1. physico-chemical characteristics of studied soils (mean of three replicates) and mean concentrations of heavy metals in studied soils and Canadian Soil Quality Guidelines (CCME, 2007) for analysed elements expressed in (mg kg-1)

\begin{tabular}{|c|c|c|c|c|}
\hline \multirow{2}{*}{ Parameter } & \multirow{2}{*}{ Kenadsa soil } & \multirow{2}{*}{ Control soil } & \multicolumn{2}{|c|}{ Canadian Soil Quality Guidelines (CCME, 2007) } \\
\hline & & & Residential/Parkland soil & Agricultural soil \\
\hline Sand (\%) & 91.18 & ND & - & - \\
\hline Silt (C) & 7.99 & ND & - & - \\
\hline Clay (\%) & 0.82 & ND & - & - \\
\hline Moisture( $\%$ ) & 2.20 & 2.5 & - & - \\
\hline $\mathrm{pH}\left(\mathrm{H}_{2} \mathrm{O}\right)$ & 7.50 & 7.88 & - & - \\
\hline $\mathrm{CEC}\left(\mathrm{cmol} \mathrm{kg}^{-1}\right)$ & 12.60 & 3.30 & - & - \\
\hline TOC (\%) & 12.60 & 0.50 & - & - \\
\hline $\mathrm{OM}^{\mathrm{a}}(\mathrm{C} / \mathrm{)}$ & 21.80 & 0.86 & - & - \\
\hline \multicolumn{5}{|c|}{ Heavy metyals (mg kg-1) } \\
\hline $\mathrm{Cu}$ & 106.6 & 2.80 & 63 & 63 \\
\hline $\mathrm{Ni}$ & 16.00 & 1.30 & 50 & 50 \\
\hline $\mathrm{Cr}$ & 22.00 & 2.60 & 64 & 64 \\
\hline $\mathrm{Zn}$ & 75.00 & 250 & 200 & 200 \\
\hline
\end{tabular}

a organic matter $(\mathrm{OM})=$ TOC $\times 1.72$ (Duchaufour ,1997) ${ }^{\mathrm{ND}}$ : not determined

\section{Concentrations of Heavy metals in studied soils}

In the absence of Algerian standards for soil quality, Concentrations of Heavy metals in studied soils were compared with Canadian Soil Quality Guidelines (CCME, 2007). They are defined as the concentrations recommended providing a healthy, functioning ecosystem capable of sustaining the existing and likely future 
uses of the site by ecological receptors and humans (Mileusnić et al., 2014). Canadian soil quality guidelines can be used as the basis for soil contamination assessment of four types of land uses: agricultural, residential/parkland, commercial, and industrial. Heavy metals concentrations in studied soils were compared with agricultural land use and residential/parkland use.

The mean values of Heavy metal contents in the kenadsa soil samples are $106.6 \mathrm{mg} \mathrm{kg}^{-1}$ for $\mathrm{Cu}, 16 \mathrm{mg} \mathrm{kg}^{-1}$ for $\mathrm{Ni}, 22 \mathrm{mg} \mathrm{kg}^{-1}$ for $\mathrm{Cr}$ and $75 \mathrm{mg} \mathrm{kg}^{-1}$ for $\mathrm{Zn}$ (Table 1). Control soil data represent Locale background values of analyzed elements in kenadsa soil.

For Copper; comparing to background value, kenadsa soil contains elevated concentration of copper (approximately 38 time higher the background value in control soil). In addition; Concentration of copper in kenadsa soil exceeds the Canadian soil quality guidelines for agricultural and residential/parkland use (CCME, 2007). Guideline values of $63 \mathrm{mg} \mathrm{kg}^{-1}$ for copper are exceeded by up to 1.63 times. For $\mathrm{Ni}, \mathrm{Cr}$ and $\mathrm{Zn}$; the results show that the mean concentrations of this element in kenadsa soil exceed the mean concentrations in control soil by a factor of 12,8 , and 3 , respectively. While these concentrations do not exceed Canadian soil quality guidelines for agricultural and residential/parkland use (Table 1). It is worthy to note, however, that, heavy metal concentrations never exceed the Canadian soil quality guidelines for agricultural and residential/parkland use in the control soil $\left(1.3 \mathrm{mg} \mathrm{kg}^{-1}\right.$ for $\mathrm{Ni}, 2.6 \mathrm{mg} \mathrm{kg}^{-1}$ for $\mathrm{Cr}$ and $25 \mathrm{mg}$ $\mathrm{kg}^{-1}$ for $\mathrm{Zn}$ ).

The results prove the anthropogenic impact on $\mathrm{Cu}, \mathrm{Ni}, \mathrm{Cr}$ and $\mathrm{Zn}$ concentrations in the kenadsa soil. The location of this studied soil in the vicinity of coking plant increased the accumulation of analyzed heavy metals. But the only analyzed element which exceeded Canadian soil quality guidelines for agricultural and residential/parkland use if the copper. If for that it chose this element for the leaching in column.

\section{Results of Column experiments}

The results of column experiments are presented as a function of the relative volume V/Vp; where $V$ denotes the volume of the cumulative leachates and $V p$ the pore volume of the column. We first present the results of the tracing experiments, and then discuss the results of column leaching under saturated conditions.

\section{Column hydrodynamics}

The Figure1 shows an example of tracer breakthrough curves (BTC) for a positive step injection and a negative step. The two curves (Figure 1 ) have a symmetry with respect to the point $\left(\mathrm{V} / \mathrm{V}_{\mathrm{p}}=1 ; \mathrm{C} / \mathrm{C}_{0}=0.5\right)$, and they are symmetrical with respect to the vertical $V / V_{p}=1$. The moments of order one and two of the RTD (Residence time distribution) are determined numerically by the trapezoid method, which made it possible to deduce the pore volume and the porosity. The average residence time of the fluid in the column is $13.3 \mathrm{~min}$ at the flow rate $2 \mathrm{ml} \mathrm{min}^{-1}$, which corresponds to a porous volume $V_{\mathrm{P}}$ of $26.6 \mathrm{ml}$ and a total porosity of 0.4 .

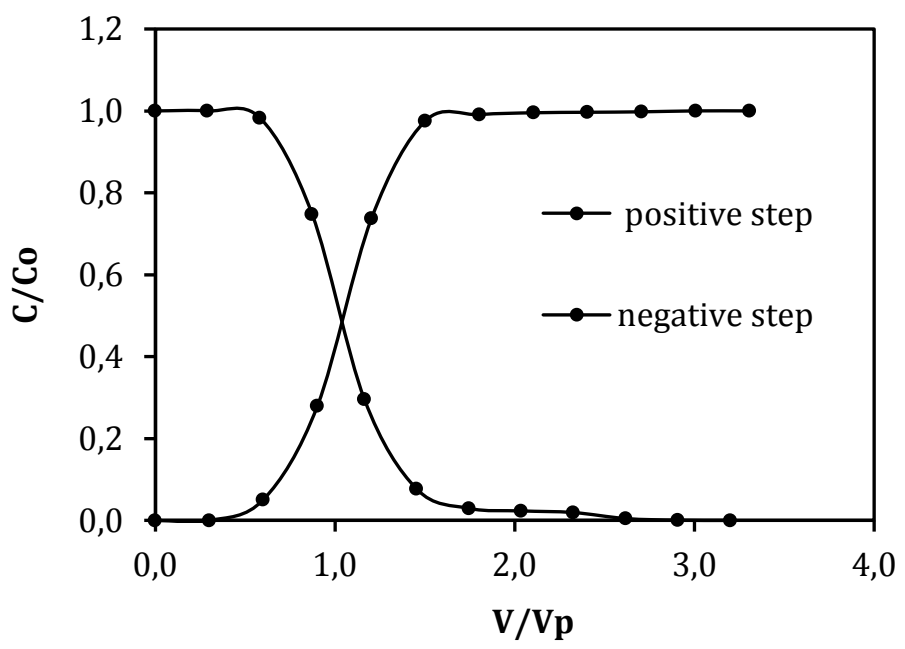

Figure 1.Response of the column to a positive step $\left(\mathrm{NaNO}_{3}\right.$ solution at $\left.10^{-2} \mathrm{M}\right)$ and a negative step

$\left(\mathrm{NaNO}_{3}\right.$ solution at $\left.2 \times 10^{-3} \mathrm{M}\right)$, with a flow rate of $2 \mathrm{ml} / \mathrm{min}$.

In addition, the differences between the volumes of water obtained by weighing the column before and after saturation and by RTD are very small (between 2 and 3\%). This shows that during the column experiments, the entire volume of water participated in the flow, indicates the absence of preferential paths or dead zones. 

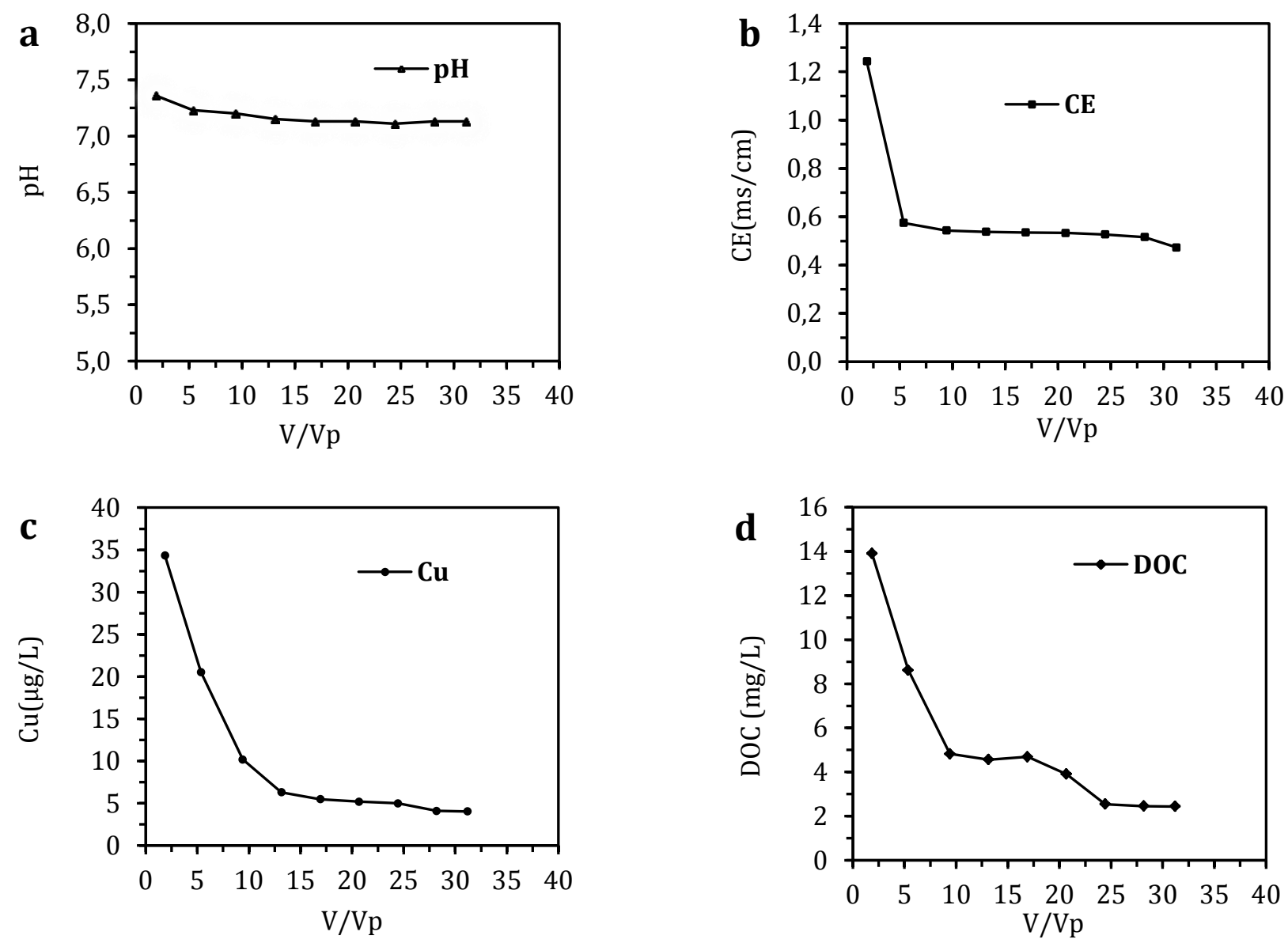

Figure 2. Result of Continuous Leaching.

$\mathrm{a}$ : $\mathrm{pH}, \mathrm{b}$ :conductivity, c: Copper concentrations, $\mathrm{d}$ : DOC concentrations; in the leachates as a function of $\mathrm{V} / \mathrm{V}_{\mathrm{p}}$.

\section{Results of continuous leaching tests \\ Evolution of the $\mathrm{pH}$ and conductivity}

The curves of Figure 2a, $2 \mathrm{~b}$ give the evolution of the $\mathrm{pH}$ and the electrical conductivity (CE) in the leachates as a function of $\mathrm{V} / \mathrm{V}_{\mathrm{P}}$. The $\mathrm{pH}$ evolves very little; it remains in the vicinity of 7.2. This $\mathrm{pH}$ is lower than that of soil in water (7.5) due to a release of organic matter during the experiment (Totsche et al., 2006). The conductivity drops sharply during the first five $V_{P}$, and then it reaches a plateau and decreases much more slowly until the end of the experiment. The conductivity measurement shows a decrease in the concentration of the elements in solution.

\section{Evolution of concentrations of Copper and DOC}

The breakthrough curve Figure2c, $2 \mathrm{~d}$ shows the evolution of copper and DOC concentrations in the leachates as a function of $\mathrm{V} / \mathrm{V}_{\mathrm{P}}$. Generally speaking, leaching is always accompanied by relatively high concentrations of $\mathrm{Cu}$ and DOC, which decrease very rapidly when percolation continues, until you reach a plateau. The effluents of the first pore volumes are coloured in yellow because of dissolved organic carbon (DOC) (Benhabib et al., 2017).

The breakthrough curves of copper (Figure 2c) have two parts. First, for about $10 \mathrm{~V}_{\mathrm{P}}$, the copper concentration at the column outlet decreases rapidly and then reaches a plateau and decreases much more slowly until the end of the experiment. The relatively high concentrations of the beginning of leaching (34.3 $\mu \mathrm{g} \mathrm{L}^{-1}$ ) are due to the solubilisation of the poorly fixed elements in the macropores of the soil. These concentrations are in fact lower than the guideline values for drinking water: $\mathrm{Cu}=2 \mathrm{mg} \mathrm{L}^{-1}$ (WHO, 2008). The equivalent of at least $20 \mathrm{~V}_{\mathrm{P}}$ was collected before the $\mathrm{Cu}$ contents stabilized at values around $4 \mu \mathrm{g} \mathrm{L}^{-1}$. This behavior has also been observed by (Xu et al., 2005) during leaching experiments on a polluted soil column at the laboratory with deionized water (DIW) at a flow rate of $1.0 \mathrm{ml} \mathrm{min}^{-1}$, The copper concentrations are of the same order of magnitude as those observed here, namely around $35 \mu \mathrm{g} \mathrm{L}^{-1}$. This observation confirms the fact that copper has a very strong affinity for the solid matrix. Moreover, Copper is more soluble and more 
mobile at $\mathrm{pH}$ values below 5 , beyond $\mathrm{pH}=7$ (which is the case here) copper is practically no longer mobile (Adriano, 1986). Several authors (Adriano, 1986; Dameron and Howe, 1998) suggest that Copper migrates slightly in depth, except in particular conditions of drainage or in a very acid medium, the copper remains strongly adsorbed in the few upper centimeters of the soil, especially on the organic matter present. In addition, the aging of the contamination is another very important factor that influences the mobility of copper; Sequestration is favored by the age of the pollution (McBride et al., 1997; Jalali and Khanlari, 2008). This is clearer when the cumulative releases of $\mathrm{Cu}$ (Table 2), does not exceed $1 \%$.

Table 2. Evaluation of the yields of copper and DOC extractions by water in column

\begin{tabular}{ccccccc}
\hline dry soil (gr) & Water $(\mathrm{mL})$ & $\mathrm{L} / \mathrm{S}\left(\mathrm{mg} \mathrm{mL}^{-1}\right)$ & $\mathrm{Cu}^{\mathrm{a}}\left(\mathrm{mg} \mathrm{kg}^{-1}\right)$ & $\mathrm{Cu}^{\mathrm{b}}(\%)$ & $\mathrm{DOC}^{\mathrm{a}}\left(\mathrm{mg} \mathrm{kg}^{-1}\right)$ & $\mathrm{DOC}^{\mathrm{b}}(\%)$ \\
\hline 83 & 830 & 10 & 0.29 & 0.29 & 173.82 & 0.14 \\
\hline
\end{tabular}

a The cumulative release of $\mathrm{Cu}$ and DOC ( $\left.\mathrm{mg} \mathrm{kg}^{-1} \mathrm{drv} \mathrm{soil}\right)$ are calculated by the relationship:

$$
Q p=\sum^{n} Q p i=\sum^{n} C p i \times(L / S) i
$$

$\mathrm{Q}_{\mathrm{p}}$ : cumulative release of $\mathrm{Cu}$ or DOC in $\mathrm{mg} \mathrm{kg}^{-1}$.

$\mathrm{Q}_{\mathrm{pi}}$ : cumulative release of $\mathrm{Cu}$ or DOC during the extraction i expressed in $\mathrm{mg} \mathrm{kg}^{-1}$.

$\mathrm{C}_{\mathrm{pi}}$ : concentration of $\mathrm{Cu}$ or DOC in the leachates resulting from the extraction $\mathrm{i}$.

$(L / S)_{i}$ : Liquid / Solid ratio of extraction i expressed in $1 \mathrm{~kg}^{-1}$.

b \% of Cu and DOC was based on pseudo total Cu and on total DOC, content in dry soil.

The same observation for DOC (Figure 2d), The DOC breakthrough curve also has two parts. First, for about $10 V_{P}$, the DOC concentration at the column outlet decreases rapidly and then reaches a plateau and decreases much more slowly until the end of the experiment. Several authors have also postponed that a DOC exit in two stages (Münch et al., 2002; Totsche et al., 2006; De Jonge et al., 2008). The high initial concentration of DOC is due to the large amount of dissolved organic carbon mobilized during the saturation of the columns (Münch et al., 2002). In addition; Temminghoff et al. (1997) found that when DOC was added to the feed solution, the solid organic matter became larger in the first two sampled layers of the columns due to coagulation.

Data in Figure 2c and 2d indicate that the leaching of copper and DOC follow the same pattern. Moreover; there is a strong correlation between eluted copper and soil organic carbon with a regression coefficient of 0.967 (Figure 3). The formation of copper-organic compounds increases at $\mathrm{pH}$ values above 7 , due to the higher solubility of soil organic matter at high pH (Adriano, 1986; Di Palma et al., 2007), especially in the pH range characterizing the studied soils $(\mathrm{pH}=7.5)$; Conversely, Copper may be complexed with DOC in the soil so that the mobility decreased (Xu et al., 2005). The relationship between DOC and copper is clear in this study. Each increase/decrease in DOC concentration is associated with a corresponding increase or decrease in $\mathrm{Cu}$ concentrations. Given the results obtained, we can suggest that the leaching of $\mathrm{Cu}$ is due to the release of $\mathrm{Cu}$ complexed with DOC; this hypothesis is consistent with the hypothesis of Zhao et al. (2007) that the DOC governed the mobilization of $\mathrm{Cu}$.

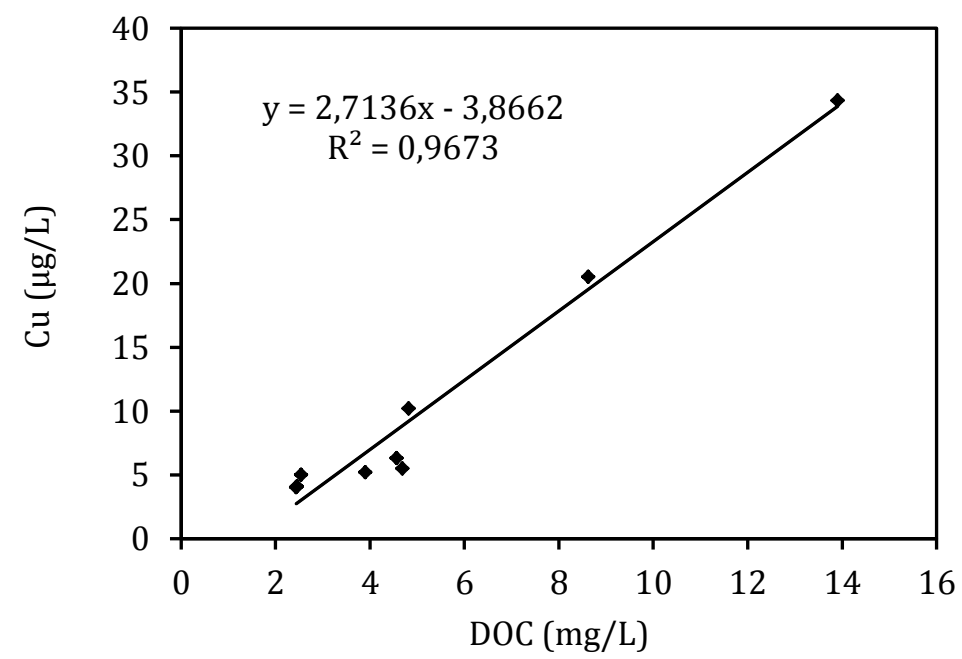

Figure 3. Evolution of $\mathrm{Cu}$ concentrations as a function of DOC concentrations during Continuous Leaching 


\section{Conclusion}

The results of analysis indicated that the kenadsa soil samples taken in the vicinity of kenadsa coking plant were contaminated by heavy metals and especially by copper. The mean concentrations of copper exceeding largely the local background value (factor of 38) and exceeded by up to 1.63 times guideline values of 63 $\mathrm{mg} / \mathrm{kg}$ for agricultural and residential/parkland use (CCME, 2007). These results prove the anthropogenic impact on $\mathrm{Cu}, \mathrm{Ni}, \mathrm{Cr}$ and $\mathrm{Zn}$ concentrations in the kenadsa soil. The location of this studied soil in the vicinity of coking plant increased the accumulation of analyzed heavy metals.

The results of column leaching testes show that, in the presence of a high organic matter content and slightly alkaline $\mathrm{pH}$, the mobility of copper is very low, the percentages leached of copper does not exceed $1 \%$ content in the soil samples.In addition, the results of column leaching testes in this study showed that the mobility of copper in Kenadsa soil is associated with the mobility of DOC. Therefore; we can conclude that under the conditions of our experimentation; potential toxicity of copper is not significant, despite its relatively high pseudo total concentration.

\section{Acknowledgement}

The authors acknowledge with gratitude the partial support of this study by the Algerian Water Service (ADE) of Sidi Bel Abbès.

\section{References}

Adriano, D.C.,1986. Trace elements in the terrestrial environment. Springer-Verlag, New York. USA. 533p.

Benhabib, K., Simonnot, M.O., Faure, P., Sardin, M., 2017. Evidence of colloidal transport of PAHs during column experiments filled with contaminated soil samples. Environmental Science and Pollution Research International 24(10): 9220-9228.

Cappuyns, V., Swennen, R., 2008. The use of leaching tests to study the potential mobilization of heavy metals from soils and sediments: A comparison. Water Air Soil Pollution 191(1-4): 95-111.

CCME, 2007. Canadian Council of Ministers of the Environment. Canadian Soil Quality Guidelines for the - Protection of Environmental and Human Health, Summary Tables, Update 7.0.

Dameron, C., Howe, P.D., 1998. Copper Environmental Health criteria n²00, World Health Organization. Geneva.

De Jonge, L.W., Moldrup, P., De Jonge, H., Celis, R., 2008. Sorption and leaching of shortterm-aged PAHs in eight European soils: Link to physicochemical properties and leaching of dissolved organic carbon. Soil Science 173(1): 13-24.

Di Palma, L., Ferrantelli, P., Merli, C., Petrucci, E., Pitzolu, I., 2007. Influence of soil organic matter on copper extraction from contaminated soil. Soil and Sediment Contamination : An International Journal 16(3): 323-335.

Duchaufour, P., 1997. Abrégé de pédologie : Sol, Végétation, Environnement. 5ème Ed. Paris, France.

ISO 23470. 2007. Soil quality, Determination of effective cation exchange capacity (CEC) and exchangeable cations using a hexamminecobalt trichloride solution.

ISO 11466. 1995. Soil quality, Extraction of trace elements soluble in aqua regia.

Jalali, M., Khanlari, Z.V., 2008. Effect of aging process on the fractionation of heavy metals in some calcareous soils of Iran. Geoderma 143(1-2): 26-40.

Kadari, H., Benhabib, K., Taleb, S., 2015. Evaluation of organic pollution from leaching water of industrial wasteland: A case study for Kenadsa region (Algerian South West). Journal of Materials and Environmental Science 6(7): 18851889.

Kalbe, U., Berger, W., Eckardt, J., Simon F.G., 2008. Evaluation of leaching and extraction procedures for soil and waste. Waste Management 28(6): 1027-1038.

Mathieu, C ., Pieltain, F., 2003. Analyse chimique des sols-Méthodes choisies. Lavoisier, France. 388p.

McBride, M., Sauve, S., Hendershot, W., 1997. Solubility control of $\mathrm{Cu}, \mathrm{Zn}, \mathrm{Cd}$ and $\mathrm{Pb}$ in contaminated soils. European Journal of Soil Science 48(2): 337-346.

Mileusnić, M., Mapani, B.S., Kamona, A.F., Ružičić, S., Mapaure, I., Chimwamurombe, P.M., 2014. Assessment of agricultural soil contamination by potentially toxic metals dispersed from improperly disposed tailings, Kombat mine, Namibia. Journal of Geochemical Exploration 144: 409-420.

Mouni, L., Belkhiri, L., Bouzaza, A., Bollinger, J.C., 2016. Chemical associations and sorption capacity of Pb and $\mathrm{Zn}$ : column experiments on a polluted soil from the Amizour mining district (Algeria). Environmental Earth Sciences 75:96.

Münch, J.M., Totsche, K.U., Kaiser, K., 2002. Physicochemical factors controlling the release of dissolved organic carbon from columns of forest subsoils. European Journal of Soil Science 53(2): 311-320.

Pichard, A., Bisson, M., Houeix, N., Gay, G., Lacroix, G., Lefevre, J.P, Magaud, H.,Migne, V.,Morin, A., Tissot, S., 2005. Copper and its derivatives, INERIS. Available at [Access date: 13.11.2017]: http://ineris.fr/substances/en/substance/getDocument/2751. 
Temminghoff, E.J.M., van Der zee, S.E.A.T.M., de Haan, F.A.M., 1997. Copper mobility in a copper-contaminated sandy soil as affected by $\mathrm{pH}$ and solid and dissolved organic matter. Environmental Science and Technology 31(4): 11091115.

Totsche, K.U., Jann, S., Kögel-Knabner, I., 2006. Release of polycyclic aromatic hydrocarbons, dissolved organic carbon, and suspended matter from disturbed NAPL contaminated gravelly soil material. Vadose Zone Journal 5(1): 469479.

Voegelin, A., Barmettler, K., Kretzschmar, R., 2003. Heavy metal release from contaminated soils: comparison of column leaching and batch extraction results. Journal of Environmental Quality 32(3): 865-875.

WHO, 2008. Guidelines for drinking-water quality - Volume 1: Recommendations, 3rd Edition. World Health Organization (WHO). WHO Press, Geneva, Switzerland. 515p.

Xu, J., Han, X., Sun, S., Meng, F., Dai, S., 2005. Leaching behavior of copper (II) in a soil column experiment. Bulletin of Environmental Contamination and Toxicology 75(5): 1028-1033.

Zhao, L.Y.L., Schulin, R., Weng, L., Nowack, B., 2007. Coupled mobilization of dissolved organic matter and metals (Cu and Zn) in soil columns. Geochimica et Cosmochimica Acta 71(14): 3407-3418. 